\title{
Sexism and Ageism in a P2P Lending Market: Evidence from Korea
}

\author{
Dongwoo KIM ${ }^{1}$
}

Received: March 12, 2020. Revised: April 23, 2020. Accepted: May 05, 2020

\begin{abstract}
This study attempts to identify gender and age discrimination by individual lenders in P2P lending markets by analyzing empirical transaction data from multiple platforms including Moneyauction, Popfunding, and 8percent. To do this, the study investigates the effects and importance of a borrower's gender and age on individual lenders' preferences and a borrower's actual repayment performance using multiple linear regression and relative weight analyses. As a result, no gender discrimination is found in the three Korean P2P lending markets, and such indiscrimination is rational, on the grounds that the borrower's gender does not have a statistically significant impact on the lenders' preferences as well as his/her actual repayment performance, and its relative importance is minimal. While, there marginally exists age discrimination against a borrower in the markets, and such ageism is likely to be irrational, on the grounds that the borrower's age has a partly significant and minimally important impact on the lenders' preferences, but has no significant and important impact on his/her repayment performance. For the first time, these findings help to clarify gender and age discrimination issues in the P2P lending market by identifying the rationality of individual lenders' preferences to the borrower's gender and age in the Korea.
\end{abstract}

Keywords : Gender Discrimination, Age Discrimination, Lender Preferences, Repayment Performance, P2P Lending

JEL Classification Code: D81, D82, G14, G41, J16.

\section{Introduction}

Thus far, institutions such as banks have mostly played the role of money suppliers in the lending market. Institutional lenders make loan decisions to customers systemically based on accumulated empirical data and an advanced IT infrastructure. Recently, however, new alternatives have been emerging due to the convergence of cutting-edge IT technology and finance. In the loan market, $\mathrm{P} 2 \mathrm{P}$ lending is the most representative form of alternative financing. The greatest difference in the P2P lending market, compared to traditional finance, is that ordinary individuals, not professional institutions, play the leading role in supplying money. These ordinary individuals participating as lenders in the P2P lending market, unlike institutional lenders in traditional loan markets, make decisions mainly

${ }^{1}$ First Author and Corresponding Author. KB Financial Group, Korea [Postal Address: 26 Gukjegeumyung-ro 8-gil, Yeongdeungpo-gu, Seoul, 07331, Korea] Email: dwkim0302@gmail.com

(C) Copyright: The Author(s)

This is an Open Access article distributed under the terms of the Creative Commons Attribution Non-Commercial License (http://Creativecommons.org/licenses/by-nc/4.0/) which permits unrestricted noncommercial use, distribution, and reproduction in any medium, provided the original work is properly cited. based on their subjective criteria with a lack of cumulative experience and a lack of infrastructure. Hence, naturally, there is much room for irrationality by individual lenders, which influences their decisions. In fact, many studies have identified irrationality in individual P2P lenders (Kim, 2020; Zhang \& Chen, 2017; Zhang, 2017).

$\mathrm{P} 2 \mathrm{P}$ lending is growing rapidly and has gained attention as an alternative to traditional finance. However, the traditional loan market continues to dwarf the P2P lending market. To ensure that P2P lending is firmly established as an alternative form of financing, the abilities of individual lenders to assess borrowers' creditworthiness should be enhanced, enabling them to make rational credit evaluations. Then, such rational assessments should induce a virtuous cycle of market development, such as ensuring interest rate competitiveness and enhancing borrowers' access to the market compared to the traditional loan market, and increasing the inflow of potential borrowers and lenders. Therefore, to this end, improving the credit rating abilities of individual lenders is an essential prerequisite.

In the P2P lending market, there are various forms of information about borrowers accessible by individual lenders when making lending decisions, including demographic, credit and financial information. However, of these aspects, 
credit and financial considerations, including borrowers' credit score, income and liabilities, are relatively easy to evaluate in that, generally, the higher the credit score, the higher the income or the lower the liabilities, the higher the borrower's ability to repay. On the other hand, it is not necessarily well known whether the borrower's gender and age relate to his/her ability to repay or not, and/or how much influence these factors have, if they are in fact relevant. In addition, individual lenders are likely to be exposed to prejudices about a borrower's gender and age depending on their previous experience and knowledge (Michels, 2012). Furthermore, if individuals continue to participate in the P2P lending market as lenders with such prejudices, their decisions are likely to be erroneous, possibly leading to poor investment performance. Moreover, if such poor investment performance continues, it will lead to a gradual exodus of existing lenders from the market and the slow entry of potential lenders, which will in turn hinder the growth of this market. Therefore, it is important to continue to provide feedback to individual lenders pertaining to the effects and importance of gender and age information through continuing analyses of cumulative empirical data on the P2P lending market.

This study focuses on the gender and age aspects of borrowers in a P2P lending market. Simply treating a person differently according to his/her gender and age is perceived as discriminatory. In addition, discrimination based on gender and age is a highly sensitive issue in society as a whole, and the loan market is no exception. In the loan market, lenders may feel that a borrower's gender and age are important factors determining his/ her creditworthiness. As a result, individual lenders may conclude that their decisions as they pertain to gender and age are irrational acts of discrimination, but reasonable consequences of logical thinking. Hence, this study seeks to investigate the effects of a borrower's gender and age and their importance to individual lenders when these lenders make lending decisions, and then discusses the rationality of their decisions.

To this end, linear regression and relative weight analyses are conducted using lender preferences and borrower repayment performance outcomes as dependent variables, the genders and ages of borrowers as explanatory variables, and other information about borrowers as control variables. In order to increase the analytical accuracy, 10,000 rounds of bootstrapping are performed for each analysis.

This study increases the possibility of generalization by analyzing and comparing data from three P2P lending platforms at the same time, unlike previous studies that mostly analyzed data from a single platform. Additionally, the study expands the regional reach of academic research on P2P lending by dealing with Korean circumstances, as most studies in this area thus far have focused on the U.S. and Chinese markets. On the methodological side, in order to minimize the interference occurring from correlations between independent variables, thereby increasing the accuracy of the analysis, relative weight analyses are accompanied by regression analyses. There is also a difference in that the relative importance of each parameter is considered beyond its statistical significance.

The results of this study are meaningful in that they identify for the first time the rationality of individual lenders' decisions about a borrower's gender and age in the Korean P2P lending market. In contrast to some P2P lending markets as well as traditional loan markets, it is confirmed that individual lenders in the P2P lending market in Korea make rational decisions regarding a borrower's gender. On the other hand, it is found that age discrimination, which has been highlighted less than gender discrimination, exists, even though it is of minimal importance, and that age discrimination in this context is irrational. Therefore, individual P2P lenders in Korea need to reflect on these findings in order to improve the accuracy of future loan decisions, considering that age discrimination against borrowers is unsupported.

The rest of the paper is organized as follows. Section 2 reviews the related literature dealing with gender and age discrimination in traditional loan markets as well as in P2P lending markets. Section 3 provides details of the empirical data and analytic methodology used here. In Section 4, the results show the effect and importance of a borrower's gender and age on individual lenders' decisions and on the repayment performances of borrowers. The rationality of individual lenders about a borrower's gender and age is discussed as conclusion in Section 5. Implications and limitations are presented in Section 6.

\section{Literature Review}

Sexism as expressed by lenders in loan markets has been a topic of interest in various academic studies. With regard to traditional loan markets, including banks and microfinance agencies, there have been many studies arguing that female borrowers are superior to males in terms of repayment performance (Anthony \& Horne, 2003; D'Espallier, Guerin, \& Mersland, 2011; Lin, Lee, \& Chen, 2011; Nanayakkara \& Stewart, 2015). Such studies have been conducted in different countries, in Pakistan (Chaudhary \& Ishfaq, 2003), Malaysia (Mokhtar, Nartea, \& Gan, 2012; Roslan \& Karim, 2009) Bangladesh (Sharma \& Zeller, 1997), the U.S. (Anthony \& Horne, 2003), China (Lin et al., 2011), and Indonesia (Nanayakkara \& Stewart, 2015). However, other studies challenge these findings. Nanayakkara and Stewart (2015) found that men 
outperformed women in terms of repayment performance in Sri Lanka. Bhatt and Tang (2002) and Godquin (2004) found that gender did not have any signal effect on loan repayment in the U.S. and Bangladesh, respectively. Many studies have shown that women have a relative disadvantage in terms of funding probabilities or loan conditions (Agier \& Szafarz; Alesina, Lotti, \& Mistrulli, 2013; Bellucci, Borisov, \& Zazzaro, 2010; Brana, 2013; Calcagnini \& Giombini, 2015; Fang \& Munneke, 2016; Fay \& Williams, 1993; Stefani \& Vacca, 2013). Such studies have been conducted in different countries, in the U.S. (Fang \& Munneke, 2016), Italy (Alesina et al., 2013; Bellucci et al., 2010; Calcagnini \& Giombini, 2015), New Zealand (Fay \& Williams, 1993), France (Brana, 2013), Germany (Stefani \& Vacca, 2013), and Brazil (Agier \& Szafarz). On the other hand, a few studies show that gender discrimination does not exist in the loan market (Cozarenco \& Szafarz, 2015; Haines, Orser, \& Riding, 1999). Cozarenco and Szafarz (2015) insist that approval for a microfinance loan was free from gender discrimination in France. Haines et al. (1999) showed that lending terms do not vary by gender in Canada.

Other studies of gender discrimination have focused on the P2P lending market. Similar to traditional lending markets, several studies have shown that female borrowers are superior to male borrowers in terms of repayment performance (D. Chen, Li, \& Lai, 2017; X. Chen, Huang, $\&$ Ye, 2019). D. Chen et al. (2017) found that the default rates of loans made to female borrowers were significantly lower than those from male borrowers in China. X. Chen et al. (2019) also insisted that lending to female borrowers is associated with better loan performance, including a lower probability of default on Renrendai, the largest $\mathrm{P} 2 \mathrm{P}$ lending platform in China. There are mixed results regarding differences in funding probabilities by gender in P2P lending markets. While D. Chen et al. (2017) argued that female borrowers were more likely to be funded than male borrowers in China, Kuwabara and Thebaud (2017) found that female borrowers seeking loans for business purposes were less likely to receive funding on Prosper in the U.S. In Korea, Kim, Maeng, and Cho (2018) found that female borrowers have a higher probability of loan success than males using data from Moneyauction. Several studies have shown that gender discrimination is not linked to funding success. X. Chen et al. (2019) did not find any measurable gender impact on funding success rates on Renrendai in China. Barasinska and Schafer (2014) also insisted that there was no effect of gender on an individual borrower's odds of receiving funds on Germany's Smava.
In the loan market, ageism is relatively less studied than sexism. In relation to traditional loan markets, Nanayakkara and Stewart (2015) argued that the older a borrower was, the better his/her repayment in the microfinance markets of Sri Lanka. Neuberger and Räthke-Döppner (2015) found that elderly people had lower interest rates than younger people in a German small business loan market, while Dunson and Reed (1991) and Epley and Liano (1999), who studied the U.S. consumer loan market, revealed that age was not related to loan success. Other studies investigated the effects of a borrower's age on their loan success in P2P lending markets. While Pope and Sydnor (2011) used Prosper data to claim that younger people under 35 were more likely to succeed in lending compared to their older counterparts, Gonzalez and Loureiro (2014) analyzed panel data obtained through a virtual platform environment and found that the older borrowers were, the more likely they were to succeed in having their loan requests funded. This study summarizes the previous literature in Table 1.

\section{Data and Methodology}

\subsection{Data}

For the analysis in this study, consumer credit loan data were collected from three Korean leading platforms, specifically Moneyauction, Popfunding, and 8percent, through a web scraping method. The Moneyauction data consist of 4,163 loans that matured in the period between June of 2007 and September of 2016, and the Popfunding data are 1,150 loans that matured in the period between January of 2011 and May of 2019. For 8percent, the data were 4,279 funded loan cases from May of 2017 to December of 2019, though not including repayment details. In each analysis, the gender and age of the borrower were adopted as explanatory variables, while the remaining factors; in this case credit, financial, and other information, were established as control variables. For the analyses to identify the effects and importance of a borrower's gender and age on individual lenders' preferences (i.e., Models I, II, and III), the number of lenders per unit amount of the loan (i.e., per 10,000 won) served as the dependent variable. Regarding the analyses to investigate the effects and importance of a borrower's gender and age on the borrower's repayment performance (i.e., Models IV and V), the redemption rate (i.e., the ratio of the actual repayment amount to the expected repayment amount) was adopted as a dependent variable. All variables are explained in detail in Table 2. 
Table 1: Summary of previous literature

\begin{tabular}{|c|c|c|c|c|c|}
\hline Type & Market & \begin{tabular}{|l|} 
What \\
aspect?
\end{tabular} & Different? & $\begin{array}{l}\text { Who are } \\
\text { superior? }\end{array}$ & Literature \\
\hline \multirow{9}{*}{ Gender } & \multirow{5}{*}{ Conventional } & \multirow[t]{3}{*}{ Repayment } & \multirow[t]{2}{*}{ Yes } & Female & $\begin{array}{l}\text { Anthony \& Horne, 2003; Chaudhary \& Ishfaq, 2003; } \\
\text { D'Espallier et al., 2011; Lin et al., 2011; Mokhtar et al., } \\
\text { 2012; Nanayakkara \& Stewart, 2015; Roslan \& Karim, } \\
\text { 2009; Sharma \& Zeller, } 1997\end{array}$ \\
\hline & & & & Male & Nanayakkara \& Stewart, 2015 \\
\hline & & & No & & Bhatt \& Tang, 2002; Godquin, 2004 \\
\hline & & \multirow[t]{2}{*}{ Funding } & Yes & Female & $\begin{array}{l}\text { Agier \& Szafarz; Alesina et al., 2013; Bellucci et al., } \\
\text { 2010; Brana, 2013; Calcagnini \& Giombini, 2015; Fang } \\
\text { \& Munneke, 2016; Fay \& Williams, 1993; Stefani \& } \\
\text { Vacca, } 2013\end{array}$ \\
\hline & & & No & & Cozarenco \& Szafarz, 2015; Haines et al., 1999 \\
\hline & \multirow{4}{*}{ P2P lending } & Repayment & Yes & Female & D. Chen et al., 2017; X. Chen et al., 2019 \\
\hline & & \multirow{3}{*}{ Funding } & \multirow{2}{*}{ Yes } & Female & D. Chen et al., 2017; Kim et al., 2018 \\
\hline & & & & Male & Kuwabara \& Thebaud, 2017 \\
\hline & & & No & & Barasinska \& Schafer, 2014; X. Chen et al., 2019 \\
\hline \multirow{5}{*}{ Age } & \multirow{3}{*}{ Conventional } & Repayment & Yes & Older & Nanayakkara \& Stewart, 2015 \\
\hline & & Interest rate & Yes & Older & Neuberger \& Räthke-Döppner, 2015 \\
\hline & & Funding & No & & Dunson \& Reed, 1991 \\
\hline & \multirow{2}{*}{ P2P lending } & \multirow{2}{*}{ Funding } & \multirow{2}{*}{ Yes } & Younger & Pope \& Sydnor, 2011 \\
\hline & & & & Older & Gonzalez \& Loureiro, 2014 \\
\hline
\end{tabular}

\subsection{Descriptive Statistics}

First, the average Number of investors per unit loan amount, a dependent variable representing the individual lenders' preferences in Models I, II and III, was 0.092 for Moneyauction, 0.577 for Popfunding, and 0.913 for 8 percent, indicating considerable differences among the platforms. The Redemption rate, a dependent variable representing the borrower's repayment performance in Models IV and $\mathrm{V}$, was 0.850 for Moneyauction and 0.857 for Popfunding. For the explanatory variable of Gender, the average ratio of male borrowers was 0.670 for Moneyauction, 0.512 for Popfunding, and 0.768 for 8 percent. Hence, male borrowers accounted for the highest portion on the 8percent platform. Regarding the explanatory variable of Age, the average age of the borrowers was 32.811 years for Moneyauction, 43.567 years for Popfunding, and 34.587 years for 8percent. Accordingly, borrowers on Popfunding were much older than those who used the other two platforms. While of all the control variables, the variables of Amount, Interest rate, and Duration were sourced from the three platforms, the average Amount was 4.791 million won for Moneyauction, 2.423 million won for Popfunding, and 8.730 million won for 8percent, again indicating major differences among the platforms. The average Interest rate was 0.305 for Moneyauction, 0.280 for Popfunding, and 0.129 for 8 percent. The average interest rates on Moneyauction and Popfunding were very high compared to that of 8percent. The average Duration was 20.352 months for Moneyauction, 14.770 months for Popfunding, and 11.220 months for 8percent, with the shortest average maturity by 8 percent. Detailed descriptive statistics of other control variables are presented in Table 3.

\subsection{Correlation Matrix}

In terms of the correlation coefficients between the variables, for Moneyauction, the coefficients were relatively high for Interest rate - External credit score (-0.488), External credit score - Internal credit score (0.483), Age Marital status (0.459), and Age - Length of work (0.437). For Popfunding, the coefficients of Amount - Duration (0.727), Marital status - Number of cohabitants (0.462), and Amount - Number of previous success $(0.410)$ were relatively high. However, for all variables, the VIF values were significantly lower than 4, thus it was assumed that the multicollinearity problem is not serious (Fox, 2016). The 8percent data showed high correlation coefficients for Interest rate - Internal 
Table 2: Variables

\begin{tabular}{|c|c|c|c|}
\hline \multicolumn{3}{|c|}{ Variables } & Explanations \\
\hline \multirow{2}{*}{\multicolumn{2}{|c|}{ Dependent }} & $\begin{array}{l}\text { Number of } \\
\text { investors }\end{array}$ & $\begin{array}{l}\text { - The average number of investors took part in each funding per ten } \\
\text { thousand won of loan amount }\end{array}$ \\
\hline & & Redemption rate & $\begin{array}{l}\text { - The ratio of the actual repayment amount to the expected repayment } \\
\text { amount for each investor }\end{array}$ \\
\hline \multirow{2}{*}{\multicolumn{2}{|c|}{ Explanatory }} & Gender & - A borrower's gender $($ Male $=1$, Female $=0)$ \\
\hline & & Age & - A borrower's age in years at the time of loan request application \\
\hline \multirow{21}{*}{ Control } & \multirow{6}{*}{$\begin{array}{l}\text { Loan } \\
\text { information }\end{array}$} & Amount & - Loan amount in ten thousand won \\
\hline & & Interest rate & - Loan interest rate \\
\hline & & Duration & - The period from loan execution to maturity in months \\
\hline & & Purpose & $\begin{array}{l}\text { - The categorical selection for the reason why a borrower wants the loan } \\
(\text { Loan repayment }=1 \text {, Others }=0)\end{array}$ \\
\hline & & $\begin{array}{l}\text { Repayment } \\
\text { method }\end{array}$ & $\begin{array}{l}\text { - The type of loan repayment }(\text { Bullet }=0 \text {, Mixed (i.e., partial bullet and } \\
\text { partial installment })=1, \text { Installment }=2 \text { ) } \\
\text { - } \quad \text { Repayment method: Mixed (Mixed }=1, \text { Others }=0 \text { ) } \\
\text { - } \quad \text { Repayment method: Installment (Installment }=1, \text { Others }=0)\end{array}$ \\
\hline & & Number of letters & $\begin{array}{l}\text { - Number of characters in text description in which the borrower expresses } \\
\text { the reason why he/she needs money and the way how he/she is planning } \\
\text { to repay the loan }\end{array}$ \\
\hline & \multirow{10}{*}{$\begin{array}{l}\text { Credit } \\
\text { information }\end{array}$} & $\begin{array}{l}\text { External } \\
\text { credit score }\end{array}$ & $\begin{array}{l}\text { - A borrower's credit score provided by third-party credit rating agencies } \\
\text { in Korea including NICE and KCB, ranging from } 0 \text { to } 1000 \text { (Han, Kang, \& } \\
\text { Shin, 2016; Park \& Yoo, 2019) }\end{array}$ \\
\hline & & $\begin{array}{l}\text { Internal } \\
\text { credit score }\end{array}$ & $\begin{array}{l}\text { - A borrower's credit score evaluated by the platform operators, for } \\
\text { Moneyauction it ranges from } 0 \text { to } 600 \text {, for 8percent it ranges from } 0 \text { to } 10 \text {, } \\
\text { by integer, respectively }\end{array}$ \\
\hline & & Income & - A borrower's monthly income in ten thousand won \\
\hline & & Bank debt & - A borrower's total debt from banks in ten thousand won \\
\hline & & $\begin{array}{l}\text { Number of } P 2 P \\
\text { debts }\end{array}$ & $\begin{array}{l}\text { - The number of loans that a borrower had provided by the platform at the } \\
\text { time of loan request }\end{array}$ \\
\hline & & $\begin{array}{l}\text { Number of usury } \\
\text { debts }\end{array}$ & $\begin{array}{l}\text { - The number of loans that a borrower had provided by usury lenders at the } \\
\text { time of loan request }\end{array}$ \\
\hline & & Credit card usage & - A borrower's monthly average amount of credit card usage \\
\hline & & Length of work & $\begin{array}{l}\text { - A borrower's total time span of working, for Moneyauction depicted in } \\
\text { months, for 8percent in years }\end{array}$ \\
\hline & & Public insurance & $\begin{array}{l}\text { - Whether a borrower subscribes the public insurance (Insured = 1, } \\
\text { Uninsured = 0) }\end{array}$ \\
\hline & & Special records & $\begin{array}{l}\text { Whether a borrower has records of special credit history including } \\
\text { bankruptcy, debt adjustment, and individual rehabilitation (Is = 1, Is not = } \\
0)\end{array}$ \\
\hline & \multirow{5}{*}{$\begin{array}{l}\text { Other } \\
\text { information }\end{array}$} & Marital status & - A borrower's marital status (Married $=1$, Single $=0$ ) \\
\hline & & $\begin{array}{l}\text { Number of } \\
\text { cohabitants }\end{array}$ & - The number of cohabitants who a borrower lives with \\
\hline & & Mobile phone & $\begin{array}{l}\text { Whether a borrower is provided his/her mobile phone number to the } \\
\text { platform operator (Provided }=1, \text { Not provided }=0 \text { ) }\end{array}$ \\
\hline & & Home phone & $\begin{array}{l}\text { Whether a borrower is provided his/her home phone number to the } \\
\text { platform operator (Provided }=1, \text { Not provided }=0 \text { ) }\end{array}$ \\
\hline & & $\begin{array}{l}\text { Number of } \\
\text { previous success }\end{array}$ & - The number of successful loan funding of a borrower on the platform \\
\hline
\end{tabular}


credit score (-0.836), External credit score - Internal credit score (0.657), Interest rate - External credit score (-0.532), Length of work - Bank debt (0.526), Age - Length of work (0.481), Income - Credit card usage (0.434). In particular, as the coefficient of Interest rate - Internal credit score was high at -0.836 and the VIF values of the two variables were also high at 5,265 and 4.118, respectively, the Internal credit score variable was excluded from the regression and relative weight analyses. Detailed correlation coefficients among the variables for each platform are shown in Tables 4, 5 and 6.

\subsection{Methodology}

Multiple linear regression and relative weight analyses (Tonidandel \& LeBreton, 2015; Tonidandel, LeBreton, \& Johnson, 2009) were conducted on each dataset.

Because both dependent variables are continuous, multiple regression analyses were performed to assess the statistical significance levels between the explanatory variables and each dependent variable for each dataset. Furthermore, relative weight analyses were conducted for each multiple linear regression model to determine the relative importance levels of the explanatory variables (Tonidandel \& LeBreton, 2015; Tonidandel et al., 2009). In order to improve the accuracy of the analysis, each analysis used standard errors for explanatory variables, which in these cases were generated through a bootstrapping method with 10,000 rounds $(\mathrm{R}=10,000)$. All analyses were performed using the statistical package $\mathrm{R}$ (version 3.5.3).

\section{Results}

\subsection{Explanatory Variables}

First, for Gender, the results of the linear regression and relative weight analyses of Models II and III show that Gender does not have a statistically significant effect on lenders' preferences, and its relative importance was also found to be insignificant. Regarding the Moneyauction data, while the linear regression analysis in Model I shows that lenders have a high preference for female borrowers at the $95 \%$ confidence level, the relative weight analysis shows that there is no statistically significant relationship between the two variables and that the importance is hence low. Compared to a linear regression analysis, of which the result could be interfered given the correlations between independent variables, because the result of the relative weight analysis is free from correlation effects, it is appropriate to consider that there is also no statistically significant effect or importance of the Gender variable on lenders' preferences in Moneyauction. Therefore, all three platforms do not show any statistical significance of Gender with regard to lenders' preferences. Based on the results of Models IV and V, while for Popfunding, female borrowers are shown to perform better than male borrowers in terms of loan repayment according to the linear regression analysis, the data for both Moneyauction and Popfunding indicate no significant effects or importance of Gender on a borrower's repayment performance when considering the results of both the linear regression and relative weight analyses. In conclusion, the results from Models I through V reveal those individual lenders do not consider the borrower's gender to be important when making loan decisions and that gender does not actually act as an important factor affecting repayment performance.

Next, for Age, the results of Model I show that individual lenders on Moneyauction prefer older borrowers, and the relative importance of Age with regard to lender preferences is significant at the $95 \%$ confidence level, although its relative weight is not high, at $0.693 \%$. In the results of Model II, in contrast, individual lenders on Popfunding favor younger borrowers, and the relative importance of Age is significant at the $99 \%$ confidence level with a relative weight of $4.921 \%$. The results of Model III show that individual lenders on 8percent have a high preference for older borrowers, as with those in Moneyauction, and although the relative weight is not high at $0.407 \%$, the relative importance of Age with regard to lender preferences is also meaningful at the $95 \%$ confidence level. Therefore, the Age variable has a statistically significant effect as regards individual lenders' preferences on all three platforms. In terms of the relative importance, however, it would be fair to say that it is not important given its minimal portion of explanatory power, although the importance has been found to be statistically significant. According to the results of Models IV and V, the Age variable is not statistically significant when assessing borrower repayment performance outcomes on both Moneyauction and Popfunding, although the linear regression analyses show statistically significant relationships between Age and the borrower's repayment performance on Moneyauction. In conclusion, although individual lenders consider a borrower's age as an important factor when making loan decisions, it is found that the importance of a borrower's age in his/her repayment performance as well as lenders' loan decision-makings is meaningless in practice.

\subsection{Control Variables}

The results of Model I show that individual lenders on Moneyauction consider the Amount and Internal credit scores to be important when making their loan decisions, with relative weights of $45.884 \%$ and $20.224 \%$, respectively. According to the results of Model II, individual lenders on Popfunding consider the Amount, Duration, and Number of previous success to be important, with relative weights of $55.642 \%, 19.667 \%$, and $10.392 \%$, respectively. From the results of Model III, Repayment method and Interest rate are likely to be considered as important in the decisions of individual lenders on 8percent, with relative weights of $34.066 \%$ and $33.490 \%$, respectively. 
Table 3: Descriptive statistics

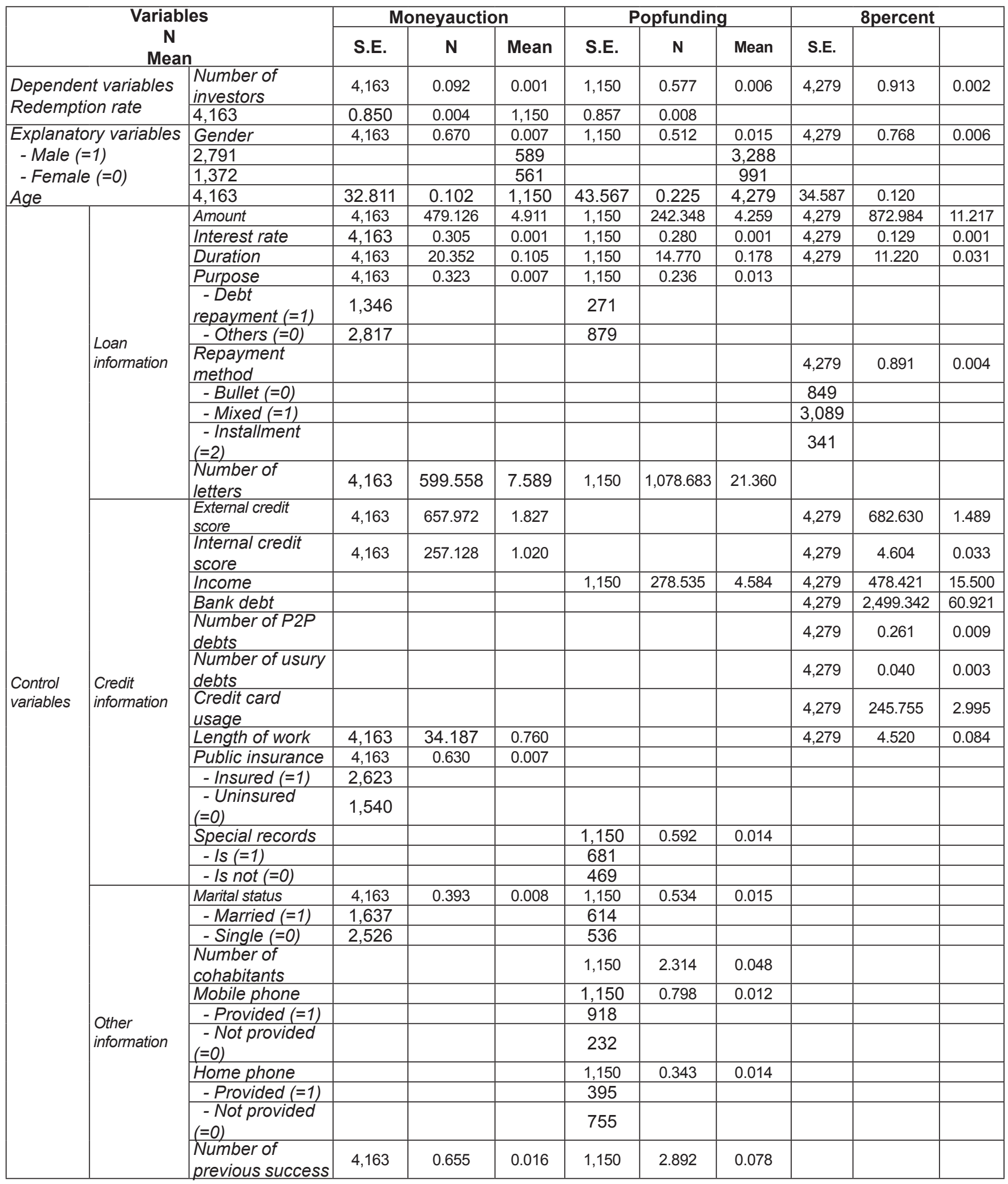


Table 4: Correlation matrix for Moneyauction

\begin{tabular}{|c|c|c|c|c|c|c|c|c|c|c|c|c|c|}
\hline Variables & (1) & (2) & (3) & (4) & (5) & (6) & (7) & (8) & (9) & (10) & (11) & (12) & (13) \\
\hline (1) Gender & 1 & & & & & & & & & & & & \\
\hline (2) Age & 0.183 & 1 & & & & & & & & & & & \\
\hline (3) Amount & 0.038 & 0.177 & 1 & & & & & & & & & & \\
\hline $\begin{array}{l}\text { (4) Interest } \\
\text { rate }\end{array}$ & -0.030 & -0.198 & -0.187 & 1 & & & & & & & & & \\
\hline (5) Duration & -0.046 & 0.025 & 0.349 & 0.014 & 1 & & & & & & & & \\
\hline (6) Purpose & -0.063 & -0.123 & 0.206 & 0.108 & 0.227 & 1 & & & & & & & \\
\hline $\begin{array}{l}\text { (7) Number of } \\
\text { letters }\end{array}$ & -0.031 & -0.094 & 0.163 & 0.103 & 0.115 & 0.100 & 1 & & & & & & \\
\hline $\begin{array}{l}\text { (8) External } \\
\text { credit score }\end{array}$ & -0.000 & 0.067 & 0.166 & -0.488 & -0.060 & -0.144 & -0.044 & 1 & & & & & \\
\hline $\begin{array}{l}\text { (9) Internal } \\
\text { credit score }\end{array}$ & 0.069 & 0.213 & 0.122 & -0.563 & -0.048 & -0.213 & -0.082 & 0.483 & 1 & & & & \\
\hline $\begin{array}{l}\text { (10) Length of } \\
\text { work }\end{array}$ & 0.060 & 0.437 & 0.180 & -0.136 & 0.021 & -0.027 & -0.077 & 0.030 & 0.218 & 1 & & & \\
\hline $\begin{array}{l}\text { (11) Public } \\
\text { insurance }\end{array}$ & 0.101 & 0.059 & 0.029 & -0.138 & 0.025 & 0.048 & -0.082 & -0.013 & 0.191 & 0.184 & 1 & & \\
\hline $\begin{array}{l}\text { (12) Marital } \\
\text { status }\end{array}$ & -0.022 & 0.459 & 0.119 & -0.089 & 0.092 & -0.089 & -0.036 & 0.014 & 0.130 & 0.261 & -0.000 & 1 & \\
\hline $\begin{array}{l}\text { (13) Number } \\
\text { of previous } \\
\text { success }\end{array}$ & -0.056 & 0.095 & -0.010 & -0.022 & -0.183 & -0.022 & 0.005 & 0.007 & 0.017 & 0.112 & -0.004 & 0.017 & 1 \\
\hline
\end{tabular}

Table 5: Correlation matrix for Popfunding

\begin{tabular}{|c|c|c|c|c|c|c|c|c|c|c|c|c|c|c|}
\hline Variables & (1) & $(2)$ & (3) & (4) & (5) & (6) & (7) & (8) & (9) & $(10)$ & $(11)$ & $(12)$ & $(13)$ & (14) \\
\hline (1) Gender & 1 & & & & & & & & & & & & & \\
\hline (2) Age & 0.210 & 1 & & & & & & & & & & & & \\
\hline (3) Amount & -0.019 & 0.192 & 1 & & & & & & & & & & & \\
\hline (4) Interest rate & -0.009 & -0.010 & -0.061 & 1 & & & & & & & & & & \\
\hline (5) Duration & -0.067 & 0.143 & 0.727 & -0.097 & 1 & & & & & & & & & \\
\hline (6) Purpose & -0.110 & -0.010 & 0.046 & -0.024 & 0.028 & 1 & & & & & & & & \\
\hline $\begin{array}{l}\text { (7) Number of } \\
\text { letters }\end{array}$ & -0.094 & -0.035 & 0.141 & 0.143 & 0.132 & 0.007 & 1 & & & & & & & \\
\hline (8) Income & -0.029 & 0.074 & -0.018 & -0.011 & -0.041 & 0.052 & -0.017 & 1 & & & & & & \\
\hline $\begin{array}{l}\text { (9) Special } \\
\text { records }\end{array}$ & -0.052 & 0.071 & 0.089 & 0.081 & 0.068 & -0.002 & 0.032 & -0.034 & 1 & & & & & \\
\hline $\begin{array}{l}\text { (10) Marital } \\
\text { status }\end{array}$ & -0.026 & 0.372 & 0.141 & 0.062 & 0.158 & 0.018 & -0.049 & 0.029 & 0.090 & 1 & & & & \\
\hline $\begin{array}{l}\text { (11) Number of } \\
\text { cohabitants }\end{array}$ & -0.141 & 0.067 & 0.123 & 0.030 & 0.131 & 0.011 & -0.009 & -0.003 & 0.112 & 0.462 & 1 & & & \\
\hline $\begin{array}{l}\text { (12) Mobile } \\
\text { phone }\end{array}$ & 0.142 & 0.002 & 0.021 & -0.116 & 0.085 & -0.032 & -0.025 & 0.015 & -0.047 & -0.074 & -0.103 & 1 & & \\
\hline $\begin{array}{l}(13) \text { Home } \\
\text { phone }\end{array}$ & 0.054 & 0.120 & -0.016 & 0.168 & -0.018 & -0.013 & 0.070 & 0.040 & 0.004 & 0.155 & 0.208 & -0.065 & 1 & \\
\hline $\begin{array}{l}\text { (14) Number } \\
\text { of previous } \\
\text { success }\end{array}$ & 0.009 & 0.143 & 0.410 & -0.121 & 0.294 & 0.025 & 0.037 & -0.033 & 0.081 & 0.023 & 0.008 & 0.065 & -0.105 & 1 \\
\hline
\end{tabular}


Table 6: Correlation matrix for 8percent

\begin{tabular}{|c|c|c|c|c|c|c|c|c|c|c|c|c|c|c|}
\hline Variables & (1) & (2) & (3) & (4) & (5) & (6) & (7) & (8) & (9) & (10) & (11) & (12) & (13) & (14) \\
\hline (1) Gender & 1 & & & & & & & & & & & & & \\
\hline (2) Age & 0.048 & 1 & & & & & & & & & & & & \\
\hline (3) Amount & 0.127 & 0.298 & 1 & & & & & & & & & & & \\
\hline (4) Interest rate & -0.065 & -0.089 & -0.258 & 1 & & & & & & & & & & \\
\hline (5) Duration & 0.098 & 0.117 & 0.308 & -0.199 & 1 & & & & & & & & & \\
\hline $\begin{array}{l}\text { (6) Repayment } \\
\text { method }\end{array}$ & 0.104 & 0.045 & 0.229 & -0.156 & 0.641 & 1 & & & & & & & & \\
\hline $\begin{array}{l}\text { (7) External } \\
\text { credit score }\end{array}$ & 0.045 & 0.056 & 0.274 & -0.532 & 0.040 & 0.046 & 1 & & & & & & & \\
\hline $\begin{array}{l}\text { (8) Internal credit } \\
\text { score }\end{array}$ & 0.076 & 0.164 & 0.369 & -0.836 & 0.087 & 0.073 & 0.657 & 1 & & & & & & \\
\hline (9) Income & 0.052 & 0.170 & 0.327 & -0.142 & 0.076 & 0.072 & 0.139 & 0.184 & 1 & & & & & \\
\hline $\begin{array}{l}\text { (10) Length of } \\
\text { work }\end{array}$ & 0.019 & 0.481 & 0.281 & -0.124 & 0.118 & 0.083 & -0.002 & 0.202 & 0.137 & 1 & & & & \\
\hline $\begin{array}{l}\text { (11) Credit card } \\
\text { usage }\end{array}$ & -0.034 & 0.172 & 0.229 & -0.040 & 0.026 & -0.003 & 0.051 & 0.095 & 0.434 & 0.205 & 1 & & & \\
\hline (12) Bank debt & 0.110 & 0.357 & 0.373 & -0.151 & 0.110 & 0.083 & 0.146 & 0.245 & 0.136 & 0.526 & 0.303 & 1 & & \\
\hline $\begin{array}{l}\text { (13) Number of } \\
\text { P2P debts }\end{array}$ & 0.007 & 0.122 & -0.021 & 0.156 & 0.135 & 0.153 & -0.010 & -0.039 & 0.029 & 0.135 & 0.108 & 0.124 & 1 & \\
\hline $\begin{array}{l}\text { (14) Number of } \\
\text { usury debts }\end{array}$ & -0.009 & -0.007 & 0.054 & 0.068 & 0.063 & 0.065 & -0.048 & -0.112 & -0.025 & -0.003 & -0.033 & -0.039 & -0.019 & 1 \\
\hline
\end{tabular}

On the other hand, according to the results of Model IV, the variables that are significantly related to borrower repayment performance outcomes on Moneyauction are, in order, Number of previous successes and Duration, with relative weights of $64.180 \%$ and $11.285 \%$, respectively. For Popfunding, the results of Model V show that the variables that have significant effects on repayment performance are, in order, Number of previous success, Mobile phone (i.e., a variable representing whether the borrower provided his/her mobile phone number to Popfunding), and Special records (i.e., a variable representing whether the borrower has some type of special credit history, such as a debt adjustment or bankruptcy, among others), with relative weights of $66.616 \%, 11.308 \%$, and $9.614 \%$, respectively. Comparing these factors to the major decisionmaking components from Models I, II and III, it can be seen that there are significant differences between the factors that individual lenders consider important when making decisions and the factors that in fact have a significant impact on actual borrower repayment performance outcomes. 
Table 7: Results of linear regression and relative weight analyses on funding

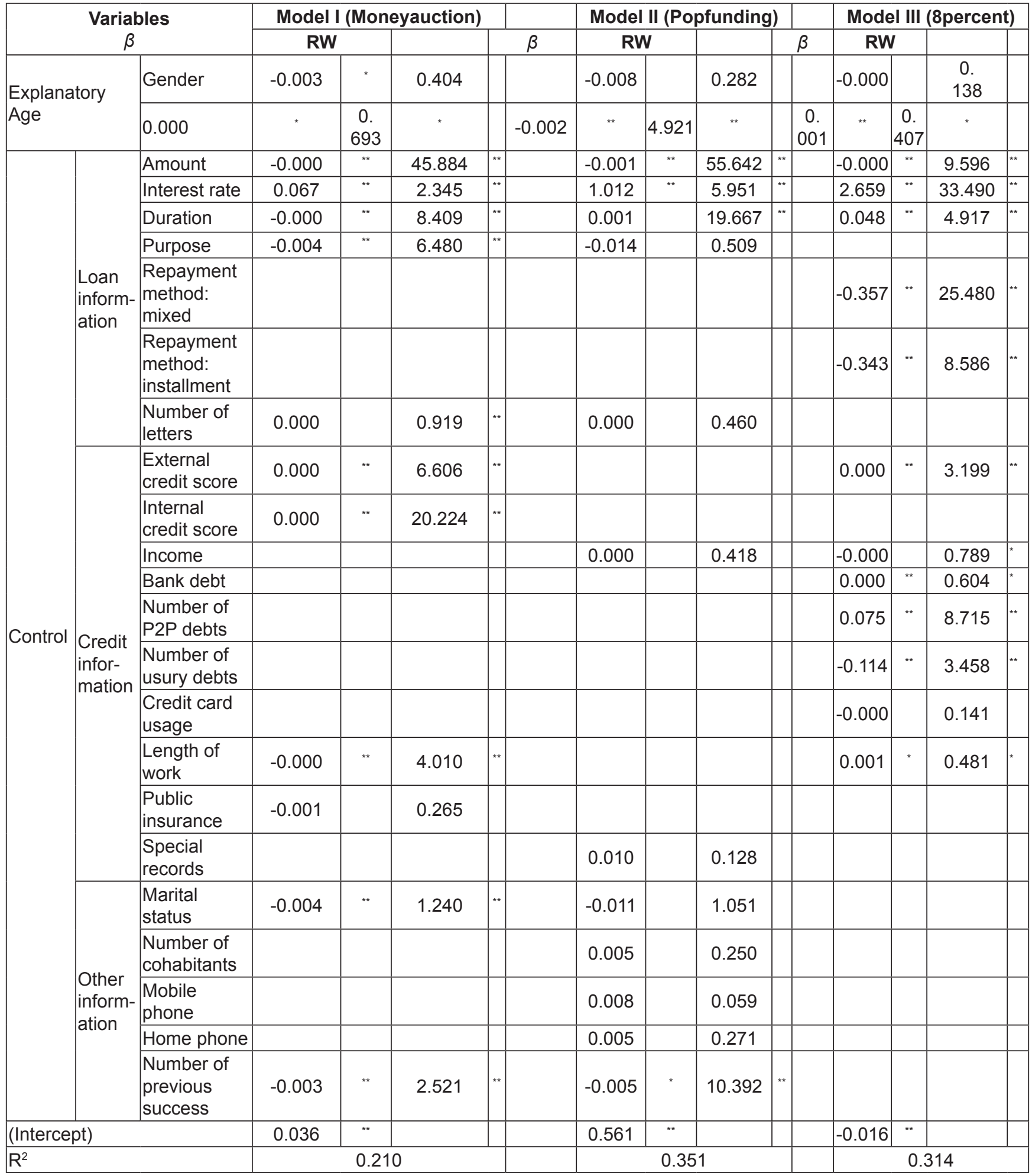

Note: $\beta$ and RW stands for the regression coefficient and relative weight, respectively.

" and ${ }^{*}$ indicate statistical significance at the $1 \%$ and $5 \%$ levels, respectively. 
Table 8: Results of linear regression and relative weight analyses on repayment

\begin{tabular}{|c|c|c|c|c|c|c|c|c|c|c|c|}
\hline \multirow{2}{*}{\multicolumn{3}{|c|}{$\begin{array}{c}\text { Variables } \\
\beta\end{array}$}} & \multicolumn{4}{|c|}{ Model IV (Moneyauction) } & \multirow[b]{2}{*}{$\beta$} & \multicolumn{4}{|c|}{ Model V (Popfunding) } \\
\hline & & & \multicolumn{2}{|c|}{ RW } & & & & \multicolumn{2}{|c|}{ RW } & \multirow[b]{2}{*}{1.669} & \\
\hline \multirow{2}{*}{\multicolumn{2}{|c|}{$\begin{array}{l}\text { Explanatory } \\
\text { Age }\end{array}$}} & Gender & -0.006 & & 0.427 & & & -0.034 & * & & \\
\hline & & -0.002 & ** & 1.004 & & & 0.002 & & 2.875 & & \\
\hline \multirow{16}{*}{ Control } & \multirow{5}{*}{$\begin{array}{l}\text { Loan } \\
\text { information }\end{array}$} & Amount & -0.000 & $* *$ & 2.652 & ** & & -0.000 & $* *$ & 3.111 & \\
\hline & & Interest rate & -0.331 & $* *$ & 4.162 & ** & & 0.303 & & 0.301 & \\
\hline & & Duration & -0.004 & ** & 11.285 & $* *$ & & 0.003 & & 2.637 & \\
\hline & & Purpose & 0.047 & ** & 2.964 & $* *$ & & -0.015 & & 0.276 & \\
\hline & & Number of letters & 0.000 & & 0.076 & & & 0.000 & & 0.120 & \\
\hline & \multirow{6}{*}{$\begin{array}{l}\text { Credit } \\
\text { information }\end{array}$} & External credit score & 0.000 & ** & 4.201 & ${ }^{* *}$ & & & & & \\
\hline & & Internal credit score & 0.000 & & 1.572 & $* *$ & & & & & \\
\hline & & Income & & & & & & 0.000 & & 0.302 & \\
\hline & & Length of work & 0.000 & $*$ & 1.521 & $*$ & & & & & \\
\hline & & Public insurance & 0.047 & ** & 5.816 & $* *$ & & & & & \\
\hline & & Special records & & & & & & 0.063 & ** & 9.614 & ** \\
\hline & \multirow{5}{*}{$\begin{array}{l}\text { Other } \\
\text { information }\end{array}$} & Marital status & 0.006 & & 0.138 & & & -0.005 & & 0.191 & \\
\hline & & Number of cohabitants & & & & & & 0.005 & & 0.482 & \\
\hline & & Mobile phone & & & & & & 0.091 & ** & 11.308 & ** \\
\hline & & Home phone & & & & & & -0.004 & & 0.499 & \\
\hline & & $\begin{array}{l}\text { Number of previous } \\
\text { success }\end{array}$ & 0.072 & $* *$ & 64.180 & $* *$ & & 0.037 & $* *$ & 66.616 & ** \\
\hline \multicolumn{3}{|c|}{ (Intercept) } & 0.909 & ** & & & & 0.495 & ** & & \\
\hline \multicolumn{3}{|l|}{$\mathrm{R}^{2}$} & \multicolumn{4}{|c|}{0.129} & & \multicolumn{4}{|c|}{0.149} \\
\hline
\end{tabular}

Note: $\beta$ and RW stands for the regression coefficient and relative weight, respectively.

"* and ${ }^{*}$ indicate statistical significance at the $1 \%$ and $5 \%$ levels, respectively.

\section{Discussion}

Analyses of the data from the three platforms show that individual lenders do not display a preference regarding a borrower's gender, and there is no significant difference with regard to borrowers' repayment performance outcomes by gender. In other words, no gender discrimination has been found in the three Korean P2P lending markets, and such indiscrimination by individual lenders is rational. The results of this study are similar to those of Barasinska and Schafer (2014), who analyzed Prosper data, but they differ from the findings of other studies that identified gender discrimination in individual lenders' funding decisions (D. Chen et al., 2017; X. Chen et al., 2019; Kuwabara \& Thebaud, 2017; Pope \& Sydnor, 2011). In addition, the finding of this study that gender differences do not affect borrowers' repayment performance outcomes contradicts the results of $\mathrm{D}$. Chen et al. (2017) and X. Chen et al. (2019), who found that female borrowers outperform male borrowers in terms of loan repayment. Considering that gender discrimination has been confirmed in a number of previous studies of traditional loan markets and P2P lending markets, it is believed that individual lenders in the Korean $\mathrm{P} 2 \mathrm{P}$ lending market are making good decisions about a borrower's gender, despite the fact that they are unskilled ordinary individuals who do not have much credit assessment experience.

As regards the borrower's age, it is found that although individual lenders discriminate borrowers according to their ages, the importance of the age discrimination is so minimal that its impact on the overall lenders' preferences is very limited. There is no significant difference in the repayment performance outcomes of borrowers with regard to their age. In the end, there minimally exists age discrimination against borrowers in the Korean P2P lending market, but such ageism is likely to be irrational. Therefore, it is necessary to continue to provide feedback about the effects of borrowers' 
ages on individual lenders' preferences and about borrowers' repayment performances to help individual lenders make better decisions in the future. The results of this study are similar to the results of Pope and Sydnor (2011), who also found age discrimination in that younger borrowers are more likely to succeed in funding, and to Gonzalez and Loureiro (2014), who found that older borrowers are more likely to receive larger loans. I summarize the research findings and their consequences in Table 9.

The results of the correlation analyses conducted here show relatively high correlations between the Age variable and certain other independent variables, in this case Length of work, Marital status, and Bank debt. Thus, if only a linear regression analysis is performed, the possibility that the above correlations between variables can affect the statistical significance can be overlooked. To this end, the accompanying relative weight analysis, which eliminates the effects of correlations between variables, allows for a more accurate interpretation of the results. For example, the results of Model IV in this study show that the Age variable has a statistically significant effect on the Redemption rate variable, at the $99 \%$ confidence level, but the results of the relative weight analysis say that this relationship is not statistically significant. Furthermore, the relative importance of the Age variable shows a very small weight (i.e., 1.004\%) compared to those of the Number of previous success (i.e., $64.180 \%$ ), Duration (i.e., 11.285\%), Public insurance (i.e., $5.816 \%$ ), External credit score (i.e., 4.201\%), and Interest rate variables (i.e., $4.162 \%$ ). When summing up these results, it appears to be proper to judge that a borrower's age is not significantly related to his/her repayment performance. Therefore, the results of many previous studies may be relatively limited in their interpretations in that they have thus far discussed the effects of the gender or age of a borrower on individual lenders' decisions or their repayment performance based solely on a regression analysis.

\section{Conclusion}

\subsection{Implication}

The findings here help to clarify gender and age discrimination issues in the $\mathrm{P} 2 \mathrm{P}$ lending market by identifying for the first time the rationality of individual lenders' decisions regarding the gender and age of borrowers in the Korean P2P lending market. In addition, while most existing studies related to P2P lending analyze data from a single platform, in this study, it is possible to strengthen the generalization of the findings given the analyses of data from three platforms at the same time. Thus far, given that previous studies of $\mathrm{P} 2 \mathrm{P}$ lending were mostly based on data from platforms in the U.S. and China, the findings of the present study contribute to expanding the regional reach of such findings in the academic research given that they focus on Korean platforms. Furthermore, most studies related to individual lenders' decisions or borrowers' repayment performance outcomes in the P2P lending market thus far have interpreted their results based solely on the statistical significance levels of the relationships between variables. However, such analyses have limitations in that they cannot completely exclude interference effects of any correlations between explanatory variables. This study attempts to analyze the results by eliminating the correlation effects between explanatory variables through a relative weight analysis. There is also a difference in that this study considers the relative importance of each variable, going further than a statistical significance test. While most existing studies focused mainly on gender discrimination, this study investigates age discrimination as well.

Table 9: Summary of research framework and results

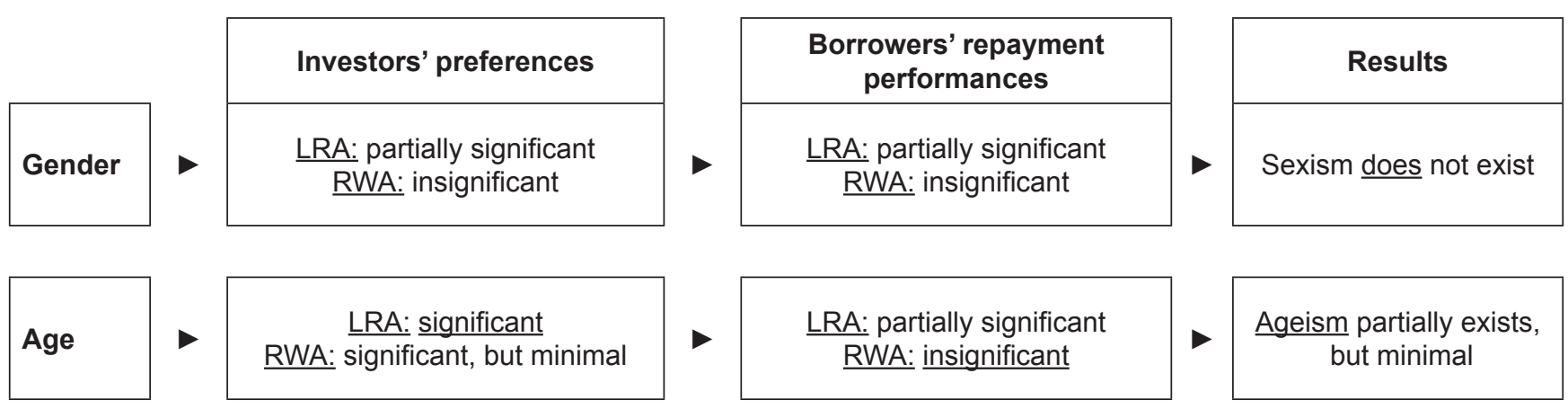




\subsection{Limitations}

In this study, the analysis of the effects of a borrower's gender and age on their repayment performance on the 8percent platform was not performed due to the limited availability of data. An additional analysis, which may show that a borrower's gender and age are also statistically unrelated to their repayment performance on 8percent can strengthen the generalizability of the findings of this study.

This study uses the number of investors relative to the loan amount as a dependent variable to analyze individual lenders' preferences. However, only one dependent variable may present limitations when identifying individual lenders' preferences in that funding amounts differ according to the lender and bidding periods vary depending on the transaction. A more accurate analysis is expected to be possible if further indicators representing individual lenders' preferences, which reflect certain individual lenders' aspects, can be utilized.

\section{References}

Agier, I., \& Szafarz, A. Microfinance and gender: Is there a glass ceiling in loan size? World Development, 42, 165-181.

Alesina, A. F., Lotti, F., \& Mistrulli, P. E. (2013). Do women pay more for credit? Evidence from Italy. Journal of the European Economic Association, 11(S1), 45-66.

Anthony, D., \& Horne, C. (2003). Gender and cooperation: Explaining loan repayment in micro-credit groups. Social Psychology Quarterly, 66(3), 293-302.

Barasinska, N., \& Schafer, D. (2014). Is crowdfunding different? Evidence on the relation between gender and funding success from a German peer-to-peer lending platform. German Economic Review, 15(4), 436-452.

Bellucci, A., Borisov, A., \& Zazzaro, A. (2010). Does gender matter in bank-firm relationships? Evidence from small business lending. Journal of Banking \& Finance, 34(12), 2968-2984.

Bhatt, N., \& Tang, S.-Y. (2002). Determinants of repayment in microcredit: Evidence from Programs in the United States. International Journal of Urban and Regional Research, 26(2), 360-376.

Brana, S. (2013). Microcredit: an answer to the gender problem in funding? Small Business Economics, 40(1), 87-100.

Calcagnini, G., \& Giombini, G. (2015). Gender differences in bank loan access: An empirical analysis. Italian Economic Journal, $1,193-217$.

Chaudhary, M. A., \& Ishfaq, M. (2003). Credit worthiness of rural borrowers of Pakistan. Journal of Socio-Economics, 32, 675-684.

Chen, D., Li, X., \& Lai, F. (2017). Gender discrimination in online peer-to-peer credit lending: Evidence from a lending platform in China. Electronic Commerce Research, 17, 553-583.
Chen, X., Huang, B., \& Ye, D. (2019). Gender gap in peer-to-peer lending: Evidence from China. Journal of Banking \& Finance, Advance online publication.

Cozarenco, A., \& Szafarz, A. (2015). Gender biases in bank lending: Lessons from microcredit in France. Journal of Business Ethics, 147(3), 631-650.

D'Espallier, B., Guerin, I., \& Mersland, R. (2011). Women and repayment in microfinance: A global analysis. World Development, 39(5), 758-772.

Dunson, B. H., \& Reed, W. R. (1991). Age discrimination in consumer finance markets. Southern Economic Journal, 58(1), 225-239.

Epley, D. R., \& Liano, K. (1999). Borrower age differences in residential mortgage lending by commercial banks. Social Science Quarterly, 604-613.

Fang, L., \& Munneke, H. J. (2016). Gender equality in mortgage lending. Real Estate Economics, Retrieved from http://www. fmaconferences.org/Vegas/Papers/Gender_Equality_in_ Mortgage_Lending_Fang_Munneke_FMA.pdf

Fay, M., \& Williams, L. (1993). Gender bias and the availability of business loans. Journal of Business Venturing, 8, 363-376.

Fox, J. (2016). Applied regression analysis and generalized linear models (third ed.). Los Angeles: Sage Publications.

Godquin, M. (2004). Microfinance repayment performance in Bangladesh: How to improve the allocation of loans by MFIs. World Development, 32(11), 1909-1926.

Gonzalez, L., \& Loureiro, Y. K. (2014). When can a photo increase credit? The impact of lender and borrower profiles on online peer-to-peer loans. Journal of Behavioral and Experimental Finance, 2, 44-58.

Haines, G. H. J., Orser, B. J., \& Riding, A. L. (1999). Myths and realities: An empirical study of banks and the gender of small business clients. Canadian Journal of Administrative Sciences, 16(4), 291-307.

Han, S.-H., Kang, K., \& Shin, Y. S. (2016). Bond rating, corporate governance, and cost of debt: The case of Korea. Journal of Asian Finance, Economics and Business, 5(15), 5-15.

Kim, D. (2020). The importance of detailed patterns of herding behaviour in a P2P lending market. Applied Economics Letters, 27(2), 127-130.

Kim, D., Maeng, K., \& Cho, Y. (2018). Study on the determinants of decision-making in peer-to-peer lending in South Korea. Asia-Pacific Journal of Accounting \& Economics, Advance online publication.

Kuwabara, K., \& Thebaud, S. (2017). When beauty doesn't pay: Gender and beauty biases in a peer-to-peer loan market. Social Forces, 95(4), 1371-1398.

Lin, T. T., Lee, C.-C., \& Chen, C.-H. (2011). Impacts of the borrower's attributes, loan contract contents, and collateral characteristics on mortgage loan default. The Service Industries Journal, 31(9), 1385-1404. 
Michels, J. (2012). Do unverifiable disclosures matter? Evidence from peer-to-peer lending. The Accounting Review, 87(4), 1385-1413.

Mokhtar, S. H., Nartea, G., \& Gan, C. (2012). Determinants of microcredit loans repayment problem among microfinance borrowers in Malaysia. International Journal of Business and Social Research, 2(7), 33-45.

Nanayakkara, G., \& Stewart, J. (2015). Gender and other repayment determinants of microfinancing in Indonesia and Sri Lanka. International Journal of Social Economics, 42(4), 322-339.

Neuberger, D., \& Räthke-Döppner, S. (2015). The role of demographics in small business loan pricing. Small Business Economics, 44(2), 411-424.

Park, H., \& Yoo, Y. (2019). Differences among credit rating agencies and the information environment. Journal of Asian Finance, Economics and Business, 6(2), 25-32.

Pope, D. G., \& Sydnor, J. R. (2011). What's in a picture? Evidence of discrimination from Prosper.com. Journal of Human Resources, 46(1), 53-92.

Roslan, A. H., \& Karim, M. Z. A. (2009). Determinants of microcredit repayment in Malaysia: The case of Agrobank. Humanity \& Social Sciences Journal, 4(4), 45-52.
Sharma, M., \& Zeller, M. (1997). Repayment performance in group-based credit programs in Bangladesh: An empirical analysis. World Development, 25(10), 1731-1742.

Stefani, M. L., \& Vacca, V. (2013). Credit access for female firms: Evidence from a survey on European SMEs. Occasional Paper 176, Bank of Italy

Tonidandel, S., \& LeBreton, J. M. (2015). RWA web: A free, comprehensive, web-based, and user-friendly tool for relative weight analyses. Journal of Business and Psychology, 30, 207-216.

Tonidandel, S., LeBreton, J. M., \& Johnson, J. W. (2009). Determining the statistical significance of relative weights. Psychological Methods, 14(4), 387-399.

Zhang, K., \& Chen, X. (2017). Herding in a P2P lending market: Rational inference or irrational trust? Electronic Commerce Research and Applications, 23, 45-53.

Zhang, N. (2017). Rationality of investors in P2P online lending platform with guarantee mechanism: Evidence in China. Journal of Applied Finance \& Banking, 7(3), 121-135. 